Piotr Śniedziewski 


\section{Nieistniejący gatunek}

Książka Romy Sendyki Norvoczesny esej. Studium historycznej śrwiadomości gatun$k u^{1}$ wpisuje się w ramy dyskusji na temat historii eseju oraz jego klasyfikacji gatunkowej, czyli tych kwestii, które nie byly w ostatnich latach obojętne dla Michała Pawła Markowskiego, Katarzyny Chmielewskiej i Andrzeja Zawadzkiego ${ }^{2}$. Nie jest to jednak ani prosty przegląd stanowisk badawczych (co można by pochopnie zarzucić autorce po zapoznaniu się z początkowymi deklaracjami), ani próba podsumowania prowadząca do jednoznacznych wniosków i wiążących definicji. Zamierzenie jest dużo ambitniejsze, a sposób uporania się z bogatym (czasami przytłaczającym) materiałem oraz jego przejrzysta prezentacja słusznie mogą budzić w czytelniku podziw. Nowoczesny esej to podróż przez teksty literackie i teoretyczne, której celem jest nie tylko uświadomienie nam złożoności zjawiska (od Michela de Montaigne'a po współczesność), lecz także wskazanie niebezpiecznych raf (genologiczny aspekt zagadnienia). Trudno przecenić to syntetyzujące ujęcie wzbogacone dodatkowo przekonującymi analizami. Te ostatnie, choćby najbardziej skrupulatne, nie przysłaniają jednak nigdy kluczowego dla Romy Sendyki pytania: czy esej jako gatunek na pewno istnieje?

1 R. Sendyka Nowoczesny esej. Studium historycznej śviadomości gatunku, Universitas, Kraków 2006. Cytaty lokalizuję w tekście.

2 Zob. M.P. Markowski Czy moziliwa jest poetyka eseju?, w: Poetyka bez granic, red. W. Bolecki, T. Tomasik, Wydawnictwo IBL PAN, Warszawa 1995; K. Chmielewska Jak moziliwa jest poetyka (eseju)?, „Teksty Drugie” $2001 \mathrm{nr} 3 / 4$; A. Zawadzki Nowoczesna eseistyka filozoficzna w pismiennictwie polskim pierwszej potowy $X X$ wieku, Universitas, Kraków 2001. 


\section{Śniedziewski Nieistniejący gatunek}

Problem podejmowany w książce, zgodnie z badawczą intuicją sygnalizowaną w uwagach wstępnych, pozostaje zatem celowo nieostry, ponieważ karkołomne wydaje się ustalenie gatunkowych wyznaczników eseju. Dużo łatwiej powiedzieć, czym esej być nie powinien, niż podać jego wyczerpujący opis. Autorka doskonale zdaje sobie z tego sprawę, więc pewne zdziwienie budzi podtytuł książki, sugerujący możliwość zapanowania nad materiałem dzięki narzędziom, które podsuwa nam poetyka historyczna. Taka perspektywa staje się mało oczywista wówczas, gdy towarzyszą jej deklaracje antyesencjalne i przekonanie (podważające arystotelesowski porządek), że na temat eseju jako gatunku nie można powiedzieć nic pewnego. Dostrzeżona wątpliwość dotyczy jednak tylko podtytułu, ponieważ w książce Roma Sendyka jest bardzo konsekwentna w obranej strategii opisu eseju. Eseju czy raczej teoretycznych wypowiedzi na jego temat - wybór ten podyktowany jest genologicznymi wahaniami i wątpliwościami, które nie pozwalają na łatwe ustalenie korpusu spełniających wszystkie wymogi „bycia esejem” tekstów (zob. s. 10-11).

Podkreślane tu napięcie między historycznie uwarunkowanymi przemianami eseju a teoretyczną przesłanką, która podaje w wątpliwość jego gatunkowy status, znalazło swój wyraz w dwóch pierwszych rozdziałach książki. Z poznawczego punktu widzenia interesujące wydają się uwagi na temat historii eseju we Francji, Niemczech i Anglii, uwagi, w których Roma Sendyka nie tylko rekonstruuje rozwój formy literackiej, lecz także wskazuje na momenty, kiedy głoszono jej anachroniczność lub nawet śmierć (s. 24-28). W proponowanej przez autorkę historycznej typologii eseju pojawiają się dwie główne tradycje: francuska z Montaigne'em jako patronem oraz angielska - z Francisem Baconem na czele. Roma Sendyka, której strategia jest wyraźnie prezentystyczna (autorka ocenia przemiany formy z perspektywy XX i XXI stulecia), skupia się na linii twórcy Prób, ponieważ - jak pisze - „dwudziesty wiek, zwłaszcza zaś jego koniec, preferowal, uprzywilejował tradycję d o ś w i a d c z e n i a, innymi słowy - opcję Montaigne'a kosztem opcji (najogólniej to ujmując) Baconowskiej" (s. 11).

Wybór to jednak cokolwiek apodyktyczny, a jego konsekwencją jest wyraźnie subiektywna ocena zjawisk historycznych, która pozwala Romie Sendyce powiązać esej (lub raczej eseistyczność) zarówno z pewną przesłanką stylistyczno-konstrukcyjną tekstu (forma pomiędzy literaturą a wypowiedzią dyskursywną charakteryzująca się niekonkluzywnością, nieciągłością, wahaniem - zob. s. 31-35), jak i teorią podmiotu (prawdziwość jednostkowego doświadczenia; wewnętrzna wolność podmiotu przeciwstawiona temu, co ogólne, systemowe, akademickie; relatywność i procesualność - zob. s. 36-43). Zaś „opcja Baconowska” (czyli tradycja eseju filozoficznego i nieco bardziej abstrakcyjnego), mimo że wcale nie mniej ważna dla literatury w XX wieku, została w omawianej pracy wyraźnie zmarginalizowana. Chodzi tu bowiem o ten typ eseju, w którym dominuje rys retoryczny i klasycyzująca postawa, co na pierwszy rzut oka nie pozwala na uznanie go za formę wyrażającą w sposób adekwatny rozterki współczesnego człowieka - a na tym przede wszystkim zależy Romie Sendyce, według której „esej jest gatunkiem 


\section{Roztrząsania i rozbiory}

wzorcowo nowoczesnym" (s. 57). I nawet jeśli autorka już na tym etapie dostrzega aporetyczny charakter gatunku (literackość i naukowość, swoboda i precyzyjność, staroświeckość i współczesność), to kolejne rozdziały przynoszą złagodzenie tej aporii, a składające się na opis eseju różnice i opozycje stają się coraz mniej wymowne z powodu obecności nadrzędnej i porządkującej kategorii, jaką jest „nowoczesność".

Nowoczesnemu charakterowi eseju, na który wskazują liczni teoretycy, podejmujący problem jego gatunkowego statusu, poświęcony jest drugi rozdział pracy. Ta część książki ma charakter odtwórczy i jest sproblematyzmowaną prezentacją stanu badań. Jej bezdyskusyjną zaletą jest pokazanie, w jaki sposób myślenie o eseju krążyło wokół zagadnień „niegatunkowości” (ze względu na zbyt dużą ilość wykluczających się cech dystynktywnych), antygatunkowości (która zwraca się przeciwko ustalonym w nauce o literaturze hierarchiom i zbliża się - choć to akurat niebezpieczne - do opisu tekstu jako wyrazu światopoglądu, co oznacza rezygnację z jego badania i przeniesienie ciężaru zagadnienia na aspekt socjoliteracki) oraz uniwersalności (gatunek istniejący przed wylonieniem się klasycznej teorii gatunków, będący też ostatnim gatunkiem - bo ku niemu prowadzą wszystkie pozostałe). W efekcie frapujące staje się pytanie o czwarty rodzaj literacki - lecz problemem jest tu ponownie wyłonienie jasnych kategorii. Stąd Roma Sendyka woli mówić o „zjawisku” eseju (s. 88), a nie o eseju jako rodzaju lub gatunku.

Wynikiem nieufności do hierarchii wywodzącej się z tradycji arystotelesowskiej jest - przedstawiona w rozdziale trzecim - próba prezentacji nieesencjalnej teorii gatunków. W tym celu autorka wykorzystuje koncept „rodziny podobieństw” Ludwika Wittgensteina oraz pojęcie prototypu w ujęciu kognitywnym. Sięgając po spostrzeżenia Davida Fishelova ${ }^{3}$, Roma Sendyka podkreśla (s. 103), że psychologia kognitywna umożliwia określenie gatunku w jego wymiarze historycznym („drzewo genealogiczne" formy literackiej) oraz semantyczno-pragmatycznym. W książce Nowoczesny esej wyraźnie dominuje druga perspektywa, która pozwala wyeliminować rozstrzygnięcia zarówno nazbyt realistyczne, jak i nominalistyczne. W konsekwencji esej określany jest jako forma posiadająca "centrum” (będące konstelacją cech najczęściej jej przypisywanych) oraz „peryferia” (na które składają się elementy pozornie mniej istotne, ale niemożliwe do wykluczenia). Szkoda, że autorka tak pospiesznie zrezygnowała z perspektywy historycznej, która wcale nie musi dotyczyć słusznie deprecjonowanych „drzew genealogicznych”. Prawdziwy problem tkwi bowiem w zupełnie innym miejscu. Roma Sendyka określa swój punkt widzenia jako antyesencjalny, a esej to dla niej forma aporetyczna (łącząca w sobie sprzeczne pierwiastki, o których pisałem już wcześniej). Porzucenie w tym kontekście historii sprawia, że dyskurs autorki Nowoczesnego eseju sam staje się aporetyczny i - wbrew założeniom - esencjalny. Kategoria prototypu, bez uwzględnienia jej historyczności oraz względności, zaczyna bowiem przypominać kategorie arystotelesowskie, roszczące sobie pretensje do uniwersalności. Tym- 


\section{Śniedziewski Nieistniejący gatunek}

czasem, co podkreślal już wiełe lat temu Hayden White ${ }^{4}$, to właśnie „wyobraźnia historyczna" wprowadza do naszego myśłenia ełementy konstruktywizmu i towarzyszącą im negacię obiektywizmu. To również dzięki tej wyobraźni "metafora" (będąca - jak u Romy Sendyki - wiązką zmiennych cech) zastępuje „opis” (dła którego strategicznym cełem jest ,wyczerpująca” i "prawdziwa” reprezentacja rzeczywistości). Dodać można jeszcze za Whitem (co pozostaje również w zupełnej zgodzie z preferowanym przez Romę Sendykę podejściem kognitywnym), że „metafora" nigdy nie tkwi w analizowanym materiale, ale jest wynikiem zabiegów poznającego podmiotu - również uwarunkowanego historycznie (podobnie jak analizowany przez niego materiał). Sądzę, że najciekawsza - jeśli pomyślimy o założeniach metodologicznych - byłaby fuzja obu wspomnianych perspektyw: historycznej oraz semantyczno-pragmatycznej.

W konsekwencji odnoszę wrażenie, iż wywody na temat psychologii kognitywnej są w recenzowanej książce nazbyt rozbudowane, jednostronne (choć Roma Sendyka nie przemilcza wątpliwości wiążących się na przykład z teorią „rodziny podobieństw" i rzetelnie je relacjonuje - zob. s. 98-103), czasami niepotrzebne (s. 103-114), skoro nawet autorka kwestionuje ich przydatność i w końcu ogranicza swe ustalenia do tez prezentowanych przez Ryszarda Nycza ${ }^{5}$. Te ostatnie umożliwiają jej stworzenie roboczej definicji eseju jako gatunku w ciagłej ewolucji, jako gatunku nieostrego, który posiada być może nawet cechy dystynktywne, ale nie mają one charakteru kategorialnego. Są raczej związane z prototypem "statystycznym" (czyli uśrednionym poglądem na temat eseju wyłaniającym się z wypowiedzi literaturoznawców), "egzemplarzowym” (dotyczącym pierwszego i rzeczywistego tekstu, który umownie otwiera historię gatunku) oraz "idealnym” (odsyłającym do nieistniejącego modelu idealnego). Te elementy wyznaczają też dalszy porządek książki.

Niezwykle ciekawy jest rozdzial czwarty, w którym Roma Sendyka stara się uporządkować krytyczno- i teoretycznoliterackie wypowiedzi na temat eseju w Polsce. Jego obecność w rodzimej literaturze zwyczajowo wiąże się z autorami renesanowymi, zaś przede wszystkim z Rozmowami Artaxesa i Ewandra Stanisława Herakliusza Lubomirskiego. Pierwsze oznaki krytycznego myślenia o eseju pojawiają się jednak dopiero wraz z pismami Stanisława Brzozowskiego. Autor Legendy Mtodej Polski w omawianej pracy raz jeszcze, po Duchu powierzchni Agaty Bielik-Robson, przedstawiony został jako ważny rewizjonista, potrafiący dostrzec pod logiczną tekstową tkanką eseju wzburzone emocje i podmiot, który miota się wśród własnych wahań, przez co i gatunek zyskuje walor "parergonu” (zob. s. 144-149).

4 Zob. H. White Brzemie historii, przel. E. Domańska, w: tegoż Poetyka pisarstwa historycznego, red. E. Domańska, M. Wilczyński, Universitas, Kraków 1999, s. 39-77.

5 Zob. R. Nycz Tekstowy świat. Poststrukturalizm a wiedza o literaturze, Wydawnictwo IBL PAN, Warszawa 1995 (chodzi o rozdz. Intertekstualność i jej zakresy: teksty, gatunki, swiaty) oraz tegoż Literatura nowoczesna: cztery dyskursy (tezy), „Teksty Drugie" $2002 \mathrm{nr} 4$. 
Refleksja Brzozowskiego jest dla Romy Sendyki punktem wyjścia do rozważań nad stanem polskiej krytyki w okresie międzywojennym. Okazuje się jednak, że nauka o literaturze ma tu niewiele do powiedzenia (dominuja spostrzeżenia samych eseistów: Bolesława Micińskiego, Karola Irzykowskiego, Jerzego Stempowskiego). Odważne sformułowania na temat eseju zawarte w pismach Micińskiego (procesualność, otwartość, metaforyczność, zawieszenie pomiędzy filozofią a literaturą) nie przełożyły się na uwagi krytyki, która była wówczas dużo bardziej zachowawcza: poszukiwała scalającego esej Ja oraz praktycznego wymiaru tekstu, który winien być przystępny i związany z życiem. Wypowiedzi krytyczne, nawet jeśli ich autorzy dostrzegali to, o czym pisali Brzozowski i Miciński, pozostawały w tyle za ustaleniami samych eseistów i często negatywnie oceniały ich nowatorskie propozycje. W efekcie Roma Sendyka stawia tezę, iż polskie literaturoznawstwo dostrzegło esej jako problem badawczy dopiero na przełomie lat pięćdziesiątych i sześćdziesiątych XX wieku (zob. s. 141, 143). W tym samym czasie pojawiają się też liczne przekłady pism Davida Hume’a, Oscara Wilde’a czy Bacona, których autorzy nie stronią od terminu esej (wcześniej zamienianego na „szkic”, „rozmyślania” czy „myśli różne”).

Druga połowa XX stulecia przynosi także pierwsze teoretycznoliterackie próby uporządkowania problematyki eseju - przełomowe okazują się zwłaszcza konstatacje Wojciecha Głowalí ${ }^{6}$. Ważną nowością jest wówczas próba określenia eseju przez wzgląd na jego „zdolność do orzekania o kondycji nowoczesnego człowieka i pasję poszukiwania odpowiedzi na podstawowe pytania egzystencji" (s. 177). W tym okresie pojawiają się również zagadnienia „eseizacji prozy”, „polskiego eseju” oraz „eseju jako świadectwa czasów przełomu” (s. 180). Na początku lat dziewięćdziesiątych XX wieku dostrzec też można, według Romy Sendyki, pierwsze próby podsumowania literaturoznawczej refleksji na temat eseju. Autorka przedstawia w tym kontekście trzy kluczowe tendencje: 1) lata sześćdziesiąte i siedemdziesiąte - w opisie eseju dominuje retoryka i poetyka, następnie tematologia; 2) lata osiemdziesiąte i dziewięćdziesiąte - na znaczeniu zyskują analizy aksjologiczne (obrona wartości humanistycznych); 3) lata osiemdziesiąte i dziewięćdziesiąte (tendencja rozwijająca się równolegle do poprzedniej) - analiza antropocentryczna, skoncentrowana początkowo na kryzysie rzeczywistości, a z czasem na pochwyceniu tożsamości poznającego Ja (zob. s. 202-203).

Najistotniejsze ustalenia, które prezentowano w ramach bogatej historii eseju oraz dwudziestowiecznej nad nim refleksji, były już w stanie zalążkowym obecne w Próbach Montaigne'a - które Roma Sendyka przedstawia jako „prototyp egzemplarzowy” i poświęca im bogaty piąty rozdział książki. Próby są w opinii autorki zarówno homogeniczne, jak i heterogeniczne (zob. s. 219), są parergonem i postergonem, prezentacją humanistycznej postawy wobec świata, ale i ciagiem autoanaliz podmiotu, który nie jest pewien własnej tożsamości. W tym sensie najlepiej wskazują na właściwy esejowi stan aporii. Z jednej bowiem strony mogą być

o W. Głowala Próba teorii eseju literackiego, „Prace Literackie” 1965 t. VII. http://rcin.org.pl 


\section{Śniedziewski Nieistniejący gatunek}

czytane z wykorzystaniem wszystkich mechanizmów, które zapewniają tekstowi spójność: kontekst epoki, biografia autora, historia kolejnych wydań. Z drugiejto tylko notatki, przygotowanie lub wprowadzenie do dzieła właściwego, prywatne zapiski kierowane do najbliższych osób. Podobnie pracę nad tekstem Pasaży definiował Walter Benjamin - zresztą jeden z bohaterów Nowoczesnego eseju. To właśnie Benjamin był świadom zarówno historycznych uwarunkowań i ograniczeń własnego zamierzenia (o czym wspomina w wielu listach adresowanych m.in. do Gretel Adorno oraz Maxa Horkheimera), jak i nietrwałości czy niekonkluzywności wypowiedzi eseistycznej - w liście do Gershoma Scholema z 26 lipca 1932 roku autor Pasazy określił swą książkę „jako miejsce ruiny czy też katastrofy, której granic nie potrafi objąć, gdy spojrzeniem wybiega w przyszłość"7. Tę bipolarność w myśleniu o eseju Roma Sendyka ogranicza jednak w związku z interpretacją Prob tylko do tych elementów, które umożliwiają „poststrukturalną” lekturę dzieła Montaigne’a. Skoro omawiana książka ma być historycznym studium świadomości gatunku, warto byłoby mimo wszystko dłużej zatrzymać się nad szesnastowiecznymi obyczajami pisarskimi, by konsekwentny prezentyzm zupełnie nie zacierał możliwych różnic między wrażliwością renesansową a współczesna. Sylwiczność ówczesnej literatury i zgoła odmienne od naszego doświadczenie życia i twórczości - na co uwagę zwraca między innymi Jean Céard ${ }^{8}$ - nie zawsze poddają się łatwej aktualizacji.

Kapitalnie za to przedstawiona została kategoria doświadczenia, która implikuje w dziele Montaigne'a autentyczność podmiotu (także poprzez zaznaczenie cielesnej obecności) oraz jego doznań i przemyśleń. W związku z zagadnieniem podmiotowości Roma Sendyka dostrzega też - zarówno u Montaigne’a, jak i późniejszych eseistów - dwa tropy Ja. Pierwszy tożsamy jest z pozytywną kumulacją doświadczeń, zasadą addytywności, pozwalającą na uspójnienie podmiotu i przesądzającą o jego ciąglości w czasie - później tak rozumiany podmiot pojawi się, według autorki, w pismach Immanuela Kanta. Być może warto byłoby się zastanowić, czy taka interpretacja podmiotowości w przypadku Kanta nie jest nazbyt jednoznaczna. Ciekawym uzupełnieniem spostrzeżeń zanotowanych w Nowoczesnym eseju wydają się uwagi, które Philippe Lacoue-Labarthe oraz Jean-Luc Nancy poczynili w książce L'absolu littéraire. Według francuskich filozofów w związku z Kantem można zasadnie mówić o kryzysie podmiotowości rozumianej w sposób substancjalny oraz o pustym cogito - taką reinterpretację i rewizję proponuje m.in. szkoła jenajska ${ }^{9}$. Autorka omawianej pracy koncentruje jednak swą uwage na innym tropie obecnym w Probach - chodzi o teorię Ja rozbitego i nieciągłego (rozwi-

7 W. Benjamin Pasaż, red. R. Tiedemann, przeł. I. Kania, posł. Z. Bauman, Wydawnictwo Literackie, Kraków 2005, s. 1001.

8 Zob. jego wprowadzenie do M. Montaigne Les Essais - Livre premier, éd. par D. Bjai, B. Boudou, J. Céard et I. Pantin, Librairie Générale Française, Paris 2002, s. 16-17.

9 Zob. Ph. Lacoue-Labarthe, J.-L. Nancy L'absolu littéraire. Théorie de la littérature du romantisme allemand, Editions du Seuil, Paris 1978, s. 39-52. 


\section{Roztrząsania i rozbiory}

janą potem między innymi przez Martina Heideggera, Sigmunda Freuda oraz Jacques'a Lacana). Nowoczesny charakter Prób wynika więc zarówno z teorii opisanego w nich podmiotu, jak również z konstrukcji samego tekstu - i te dwa elementy pozwalają Romie Sendyce określić dzieło Montaigne’a jako prototyp „egzemplarzowy”, czyli umownie otwierający historię (anty?)gatunku jakim jest esej.

Ksiązka kończy się (rozdzial szósty) przedstawieniem kilku modelowych opisów eseju (a zatem tak zwanych prototypów „idealnych”), które nigdy nie zostały zrealizowane: w tej części przywoływane są szkice Virginii Woolf, Roberta Musila, György’a Lukácsa, Maxa Bensego i Theodora W. Adorna. Autorka słusznie podkreśla, że każdy z tych pisarzy (prócz Lukăcsa, którego refleksja ma wyraźnie teleologiczny charakter) był wrażliwy na procesualność eseju, jego wariantywność i niekonkluzywny charakter. I tak u Woolf pojawia się na przykład opozycja męskie żeńskie. Drugi z tych elementów przeważa, wyrażając tym samym to, co obce systemowi, sceptyczne wobec chronologii oraz logiki. Jednak esej - by w ogóle mógł zaistnieć - musi być wyrażony w języku tradycyjnie łączonym ze sferą męską. Stąd bierze się, co istotne dla rozważań Romy Sendyki, aporetyczny charakter gatunku, który jest androgyniczną formą literacką. Także pozostali twórcy podkreślają w swych esejach o eseju dziwny status tej formy: zawieszonej pomiędzy religią a nauka, rozumem a emocjami (Musil), będącej najmniej systematyczną spośród wszystkich pozostałych (Adorno).

Ponieważ omawiając poetykę eseju, autorka przywiązuje wagę nie tylko do elementów genologicznych, tematycznych oraz ideologicznych, ale także do stylistycznej wirtuozerii, którą na ogół wiąże się z tą formą, konieczne wydaje się podkreślenie tego, w jaki sposób książka o nowoczesnym eseju została opracowana i wydana. Praca Romy Sendyki budzi bowiem wiele zastrzeżeń językowych, o których odpowiednią korektę nie zadbał edytor. Szkoda, bo to kolejna ważna i ciekawa pozycja, która pojawia się z tego rodzaju uchybieniami w cieszącej się zasłużenie dobrą sławą serii Horyzonty Nowoczesności. Zaletą wydania jest bezsprzecznie indeks nazwisk oraz problemów, co ułatwia orientację w bogatym i erudycyinie imponującym materiale zgromadzonym przez Romę Sendykę. Na uznanie zasługuje także wyczerpująca i przejrzyście skonstruowana bibliografia. Na tym tle bardziej zaskakujące stają się liczne błędy językowe: stylistyczne, interpunkcyjne, a nawet ortograficzne. Są to usterki pojawiające się od czasu do czasu w rozprawach wydawanych w Horyzontach Nowoczesności przez krakowski Universitas i martwią one przede wszystkim dlatego, że seria jest faktycznie istotna dla polskiej humanistyki - stanowi wszak cenne źródło i punkt odniesienia dla licznych prac; poza dyskusją jest również prezentowana w niej różnorodność postaw badawczych i oryginalność głoszonych poglądów.

Pozostaje mieć nadzieję, że wspomniane pomyłki będą usunięte w kolejnych wydaniach książki - jestem bowiem przekonany, iż zasługuje ona na to z kilku przynajmniej powodów. Przede wszystkim jest to praca, która po raz pierwszy w tak obszerny i wyczerpujący sposób przedstawia historię dwudziestowiecznej refleksji poświęconej esejowi. Zgromadzony w niej materiał nie tylko ukazuje różne 


\section{Śniedziewski Nieistniejący gatunek}

stanowiska badawcze czy światopoglądowe obecne w literaturze, krytyce i teorii w Polsce, ale obejmuje też najistotniejsze teksty obcojęzyczne. Po drugie, książka Romy Sendyki jest doskonalą pomocą dydaktyczną na zajęcia z poetyki, teorii oraz historii literatury. Pozwala śledzić zarówno fascynującą dyskusję na temat eseju w dwudziestoleciu międzywojennym, jak i ,hipotetyczne” narodziny formy w XVI stuleciu (poświęcony Próbom Montaigne’a precyzyjny i bogaty w ustalenia rozdział wypełnia istniejącą w polskim literaturoznawstwie lukę w tym zakresie). Nie bez znaczenia są również próby opisu eseju jako (anty)gatunku, które we frapujący sposób komplikują dyskusję na temat genologii. Po trzecie wreszcie, udało się autorce pokazać, dlaczego oraz w jaki sposób esej awansował do roli jednego z kluczowych dla współczesności gatunków. Jego niekonkluzywny charakter, krytyczne zacięcie, dystans nie tylko do świata ideologii, ale i własnej formy, sprawiaja, że w doskonały sposób wyraża wahania oraz niepewność dzisiejszych czasów oraz sceptycyzm poznawczy, który w filozofii oraz literaturze zagościł dzięki postmodernizmowi. W tym jednak kontekście ani esej, ani postmodernizm nie oznaczają myślenia bez wartości - Roma Sendyka w przejrzysty sposób dowodzi, że kluczowa jest dla nich obrona niezależnej refleksji oraz doświadczenia, które polega na ciągłym próbowaniu świata i siebie samego.

\section{Piotr ŚNIEDZIEWSKI}

\section{Abstract}

\section{Piotr ŚNIEDZIEWSKI}

\section{Adam Mickiewicz University (Poznań)}

\section{A Non-Existent Genre}

Book review: Roma Sendyka, Nowoczesny esej. Studium historycznej świadomości gatunku ['The Modern Essay. A study on historlcal awareness of the genre'], Universitas, Krakow 2006.

Ms. Sendyka's book is the first study in Polish that presents in such broad terms and so exhaustive a manner the history of twentieth-century reflection on essay. The resources collected for the purpose not only show the different scholarly or view-of-the-world positions appearlng in the reference literature, criticism and theory in Poland, but also embrace the most important foreign-language texts. The author believes that the key characterlstics of essay include inconclusivity, critical verve, and a distance to the world of ideologies and the essayist's own form alike. These premises allow one to consider essay to be one of the most important literary genres to our contemporary time. 